\title{
Diversity of Mineral Contents in Arecanut (Areca catechu L.) in Different Locations of Karnataka, India
}

\author{
B.R. Gurumurthy ${ }^{*}$, S.S. Akshatha, G. Akshay and S.K. Pavitra \\ Department of crop physiology, University of Agricultural and Horticultural sciences, \\ Shivamogga-577225, Karnataka, India \\ *Corresponding author
}

\section{A B S T R A C T}

\begin{tabular}{|l|}
\hline Ke y w o r d s \\
ICPOES, Mineral \\
nutrients, Arecanut, \\
Potassium, \\
Magnesium
\end{tabular}

A study has been undertaken to study the variability in mineral contents in areca samples collected from different districts of the Karnataka. The Nutrients were estimated using inductively coupled plasma optical emission spectrophotometer (ICPOES). The difference in elemental contents was highly significant. The higher mineral content of phosphorous $(0.30 \%)$, magnesium $(0.09 \%)$ and iron $(231 \mathrm{ppm})$ was recorded in areca samples of Hosdurga taluk of Chitradurga district but these samples were lower in copper (5.2 ppm). Koppa, N. R. Pura, Tarikere taluks Chikkamagulur district contained higher calcium (0.10 $\%)$ whereas it was lower in Kadaba of DK $(0.05 \%)$. The samples of different taluks: Harihar (K 0.47 \%), Shikaripura (Zn 27 ppm), N. R. Pura (Cu 25 ppm) and Mudigere (B $278 \mathrm{ppm})$ contained significantly higher mineral contents. The variation in the mineral nutrients might be due to soil conditions, management practices, processing technique and environmental factors. The present study is imminent. Since the major portion of areca is used for human consumption. Further, it has been inferred that, considering the concentration of these minerals limit of areca for human consumption might be $166 \mathrm{~g}$ per day per person and it varies with the change in mineral contents in areca samples.

\section{Introduction}

Arecanut (Areca catechu L.), is highly profitable commercial plantation crop in India. Areca is used for preparing ayurvedic and Chinese medicines which are believed to cure unusual kind of diseases. Areca nut is known colloquially known as supari in hindi and other languages in India, puwak in Sri Lanka, gua in Sylheti (Bangladesh) and mak in Thailand. The major constituents of the nut are carbohydrates, fats, proteins, crude fibre, polyphenols (flavonols and tannins), alkaloids and mineral matter (Raghavan and Baruah., 1958). The nut contains six related alkaloids of which four (arecoline, arecaidine, guvacine and guvacoline) have been conclusively identified in biochemical studies (Lord et al., 2002). The powdered areca is used as tooth powder for maintaining the endurance of the teeth and also to clean the intestinal tracts and worms inside our stomach or by decoction or using the alkaloid extracted capsules. The Ayurvedic note says "the intake of areca with betel leaves freshens the breath". At the same time this combination completely changes a 
person into a psychoactive mentality but no effects on the concentration and memory. The major constituents of the nut are carbohydrates, fats, proteins, crude fibre, polyphenols (flavonols and tannins), alkaloids and mineral matter (Balasimha et al., 2004). Variations in the concentrations of the various constituents may occur in nuts from different geographical locations and according to the degree of maturity of the nut. The ICPOES is the most commonly employed technique in modern laboratory for the determination of nutrient elemental concentrations in a wide range of samples. It is a analytical technique for the detection of trace metals with greater accuracy.

It is a type of emission spectroscopy that uses the inductively coupled plasma to produce excited atoms and ions that emit electromagnetic radiation at wavelengths characteristic of a particular element. It is a flame technique with a flame temperature in a range from 6000 to $10000 \mathrm{~K}$. The intensity of the emission is indicative of the concentration of the element within the sample. Globally 90 per cent of total areca produce is utilized for human consumption in one or other forms, through which approximately 965 thousand tons of areca has become of part of human diet and hence study of mineral content and variability is of greater importance.

\section{Materials and Methods}

Arecanut samples were collected from different districts of Karnataka (Shimoga, Davanagere, Chikkamagalur, Chitradurga, Udupi and DK). Initially 850 samples were collected from different locations, pooled on hobli basis and the pooled 152 samples were subjected to inorganic nutrient analysis. The samples subjected to liquid chemical digestion process and filtered to obtain clear digested sample which is used for elemental analysis in ICPOES instrument.
Digested samples are pumped through a nebulizer to produce a fine spray. Large droplets are removed by a spray chamber, small droplets then pass through the center tube in the torch to the plasma. Solvent is evaporated and the residual sample decomposes to atoms and ions that are excited by the electrical radio frequency generated plasma to $9000 \mathrm{k}$ that will emit a unique set of wavelengths of light for each element as they decay to a lower energy state. The intensity of this light is measured and this corresponds to the concentration of element type in the original sample.

In Nebulization the sample is converted to a mist of finely divided droplet called aerosol. Where the sample is sucked in to capillary tube by a high pressure stream of argon gas flowing around the tip of the tube. This pressure breaks the liquid into fine droplets in various sizes in the spray chamber. In the spray chamber, separation of aerosol occurred where the large droplets go to drain, the fine droplet carried to the plasma. More than $99 \%$ of the injected sample goes to drain and less than $1 \%$ carried out to the plasma. The plasma is a highly energized cloud of gaseous ions and their electrons. Inductively coupled plasma source is called torch. It is consist of three concentric tubes through which streams of argon gas flow.

Depending upon the torch design, the total rate of argon consumption is $5-10 \mathrm{~L} / \mathrm{min}$. The temperature of the plasma is varying in different sections ranging from 2000 to $9000 \mathrm{~K}$ but it is considered to be relatively uniform. Peristalic pump draws converts the sample solution and delivers it to the nebulizer. Radio frequency generator generates an oscillating electromagnetic field at a frequency of 27.12 million cycles per second. Load coil delivers the radiation to the torch. The torch has argon flowing through it which will form plasma in the RF field. 
The multi elemental standards of ICP grades were fed to the instruments to obtain the standard curves and for calculation of elemental contents in the samples.

\section{Results and Discussion}

Potassium helps in maintaining ionic balance in the cell, water relations and helps in root development. It is necessary for the formation of sugar, fat and fibrous materials and also favours early bearing. According to standard nutritional data, potassium content in areca is $450 \mathrm{mg}$ (Cheriyan and Manojkumar, 2014). The data on the potassium content of different districts is presented in Figure 1(a). Among the taluks of different districts, Harihara of Davanagere district recorded significantly higher Potassium content $(0.47 \%)$ which was followed by Davanagere taluk of Davanager district $(0.44 \%)$. Significantly least potassium content was recorded in the Bhadravathi taluk of Shimoga district $(0.17 \%)$.

The data on the phosphorous content of different districts is presented in the Figure 2(b). Among the districts phosphorous contents recorded significant difference and ranged from 0.08 to $0.30 \%$. The highest phosphorous content was recorded in Hosadurga taluk of Chitradurga district ( 0.3 $\%$ ) which was followed by Hiriyur taluk of Chitradurga district $(0.29 \%)$. The least phosphorous content was recorded in Bantwala taluk of DK $(0.08 \%)$.

The contents of calcium in different districts and taluks are presented in Figure 2(a). Calcium content varied significantly among the different districts of Karnataka (0.05-0.10 $\%)$. Chikkamagalur, Koppa, N. R. Pura and Tarikere of Chikkamagalur district recorded significantly higher calcium content $(0.10 \%)$. Significantly the least calcium content was recorded in Kadaba of DK, Kundapura of Udupi, Harihara of Davanagere $(0.05 \%)$.
The data on the magnesium content of different districts and taluks in presented in Figure 2(b). Magnesium content in different districts recorded significant difference which varied from 0.04 to $0.09 \%$. Hosdurga of Chitradurga district recorded significantly higher magnesium content $(0.09 \%)$ followed by Udupi taluk of Udupi district $(0.08 \%)$. Chikkamagalur district recorded significantly lower magnesium content $(0.04 \%)$.

According to standard nutritional data, iron content in areca is $4.9 \mathrm{mg}$ (Shivashankar et al., 1969). The data on the iron content of different districts is presented in Figure 3(a). Among the taluks of different districts iron content recorded significant difference with the range of 88.70 to $231.50 \mathrm{ppm}$. Holalkere taluk of Chitradurga district recorded significantly higher iron content $(231.50 \mathrm{ppm})$ followed by Hosdurga taluk of Chitradurga district $230.80 \mathrm{ppm})$. Significantly least iron content was recorded in the Kundapura taluk of Udupi district (70.60 ppm).

The Zinc content varied in different districts of Karnataka (7.30 to $27.46 \mathrm{ppm}$ ) and the data presented in Figure 3(b). Sagar taluk of Shimoga district recorded significantly higher zinc $(27.46 \mathrm{ppm})$ followed by Shikaripura taluk (22.58 ppm). Significantly least zinc content was recorded in Harihar taluk of Davanagere district (6.40 ppm).

Copper is used in wide range of medicine and it also aids in iron absorption. Copper content in different districts recorded significant variability with the range of 5.20 to $25.73 \mathrm{ppm}$ and presented in Figure 4(a).

N. R. Pura of Chikkamagalur district recorded significantly higher copper content (25.73 ppm) followed by puttur taluk of DK district (24.50 ppm). Hosadurga taluk of Chitradurga district recorded significantly lower copper content (5.20 ppm). 
Fig.1 Taluk wise variability in Potassium and Phosphorous contents in areca samples of different districts of Karnataka

(a) Potassium

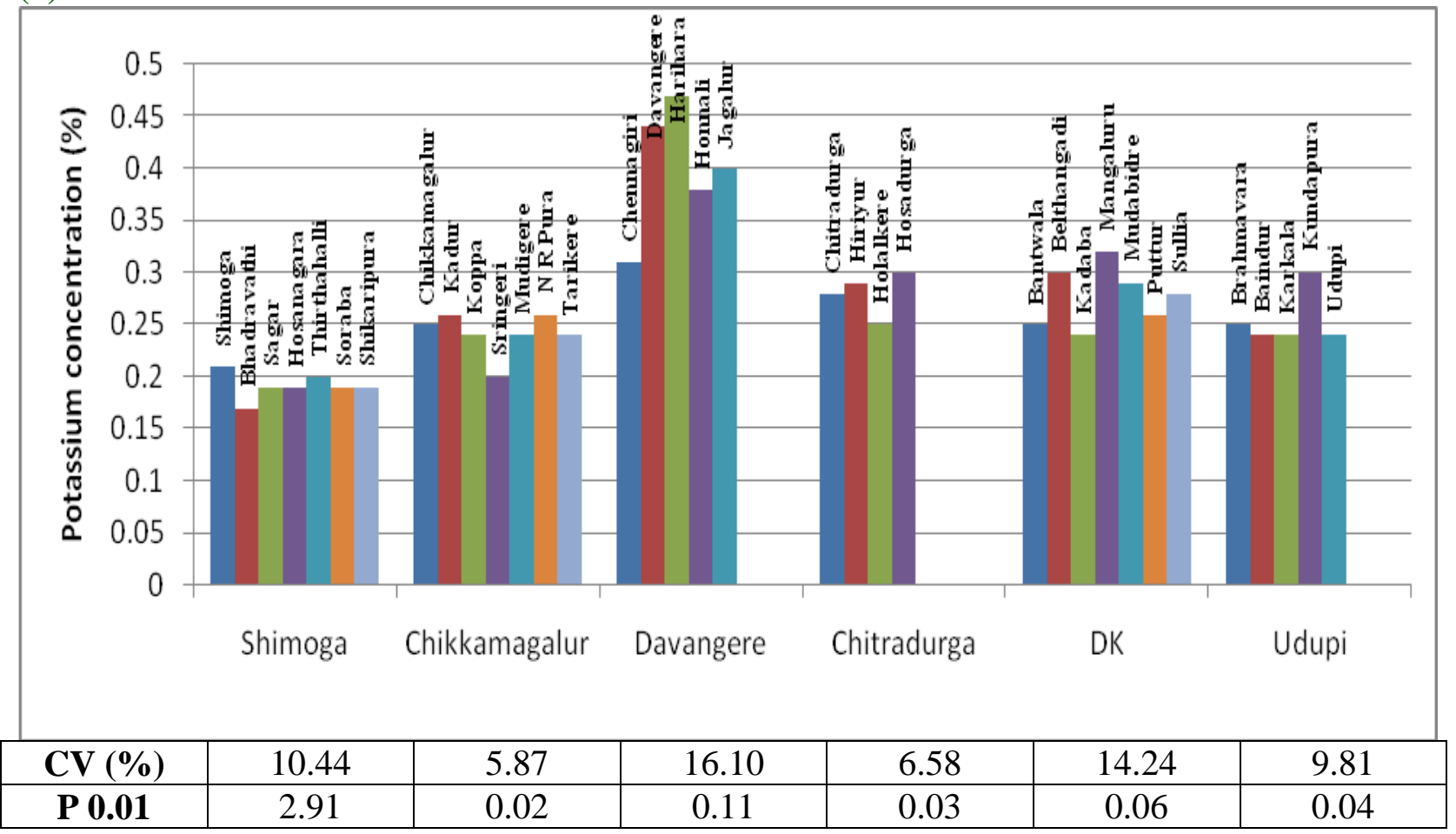

(b) Phosphorous

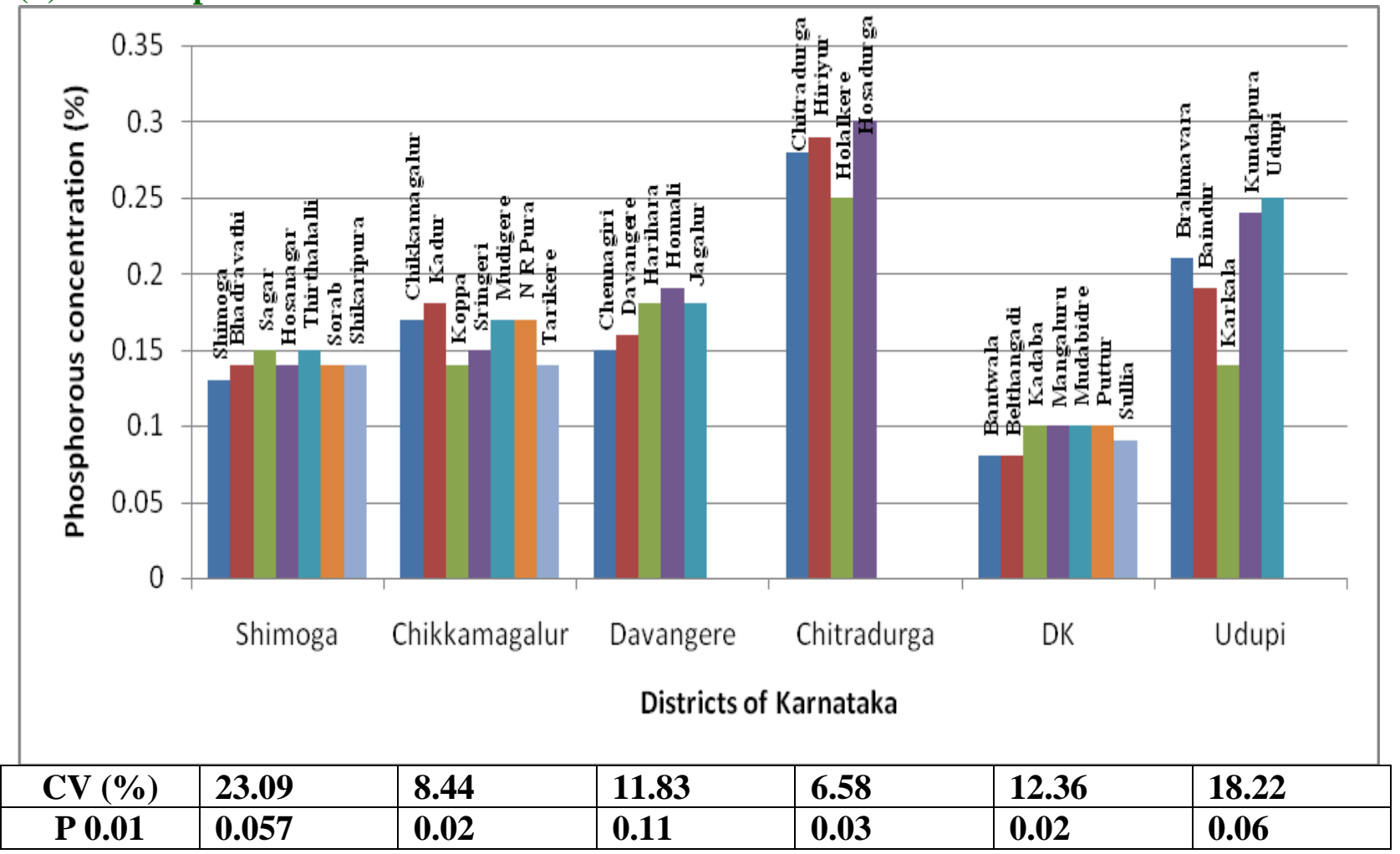


Fig.2 Taluk wise variability in Calcium and Magnesium contents in areca samples of different districts of Karnataka

(a) Calcium

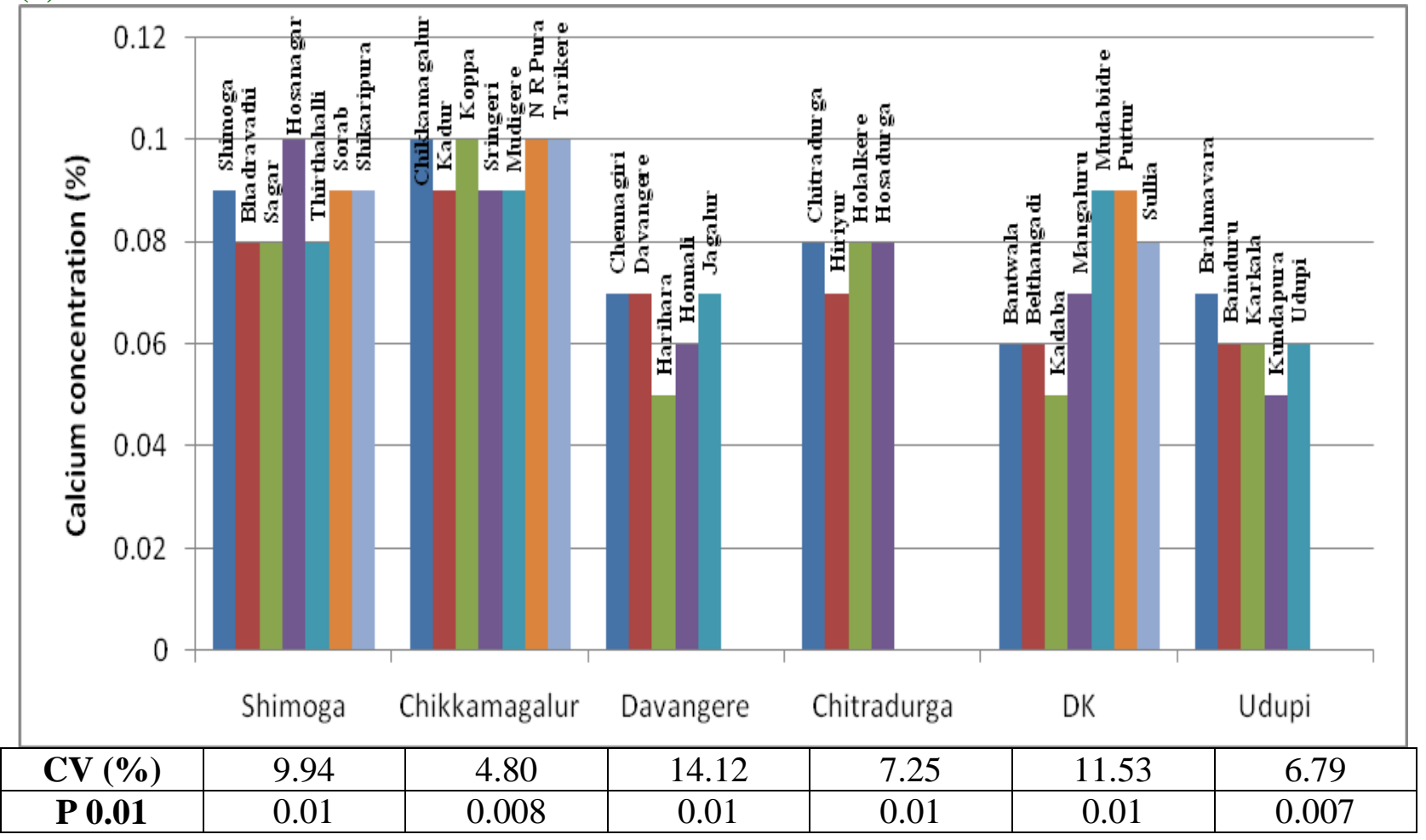

(b) Magnesium

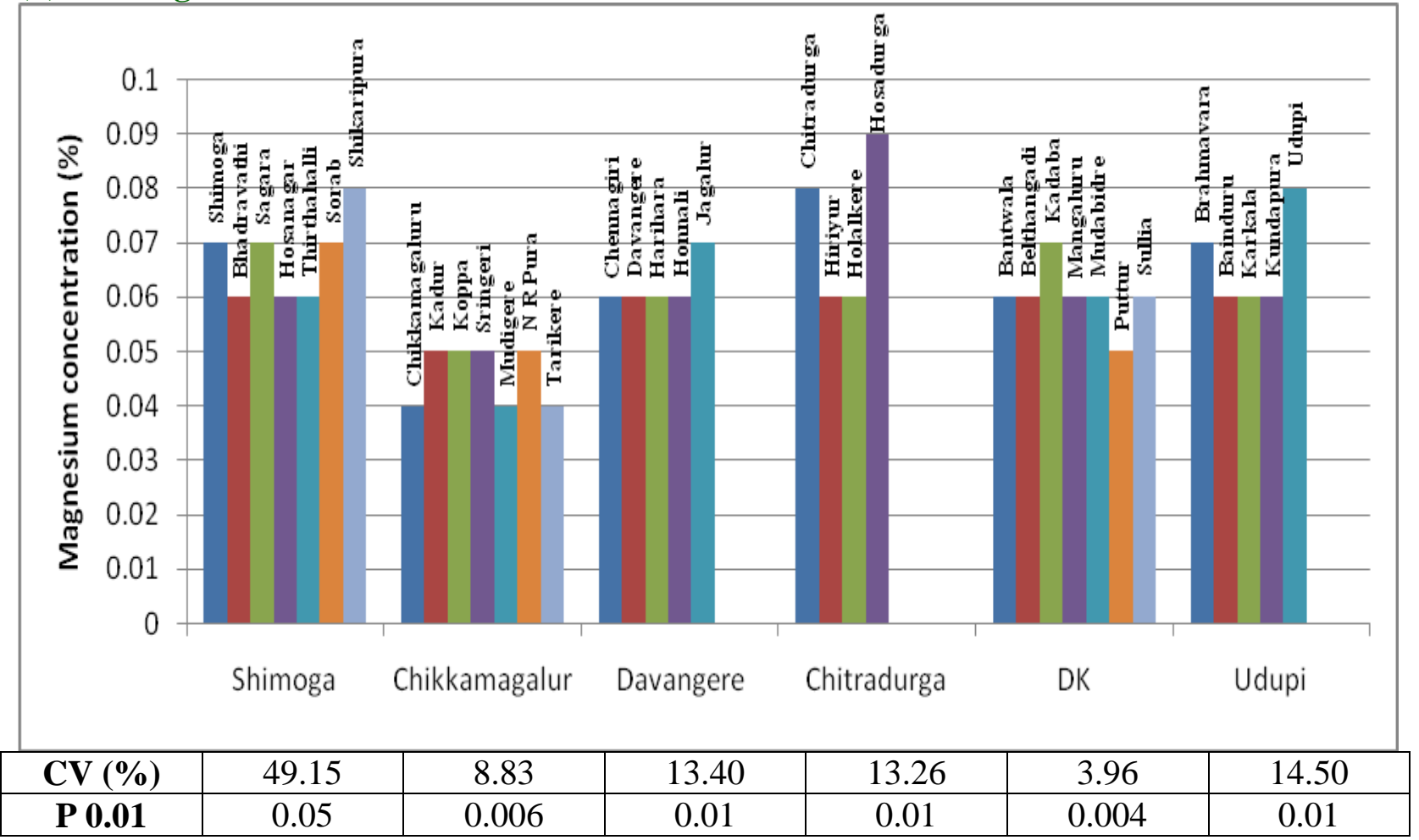


Fig.3 Taluk wise variability in Iron and Zinc contents in areca samples of different districts of Karnataka

(a) Iron

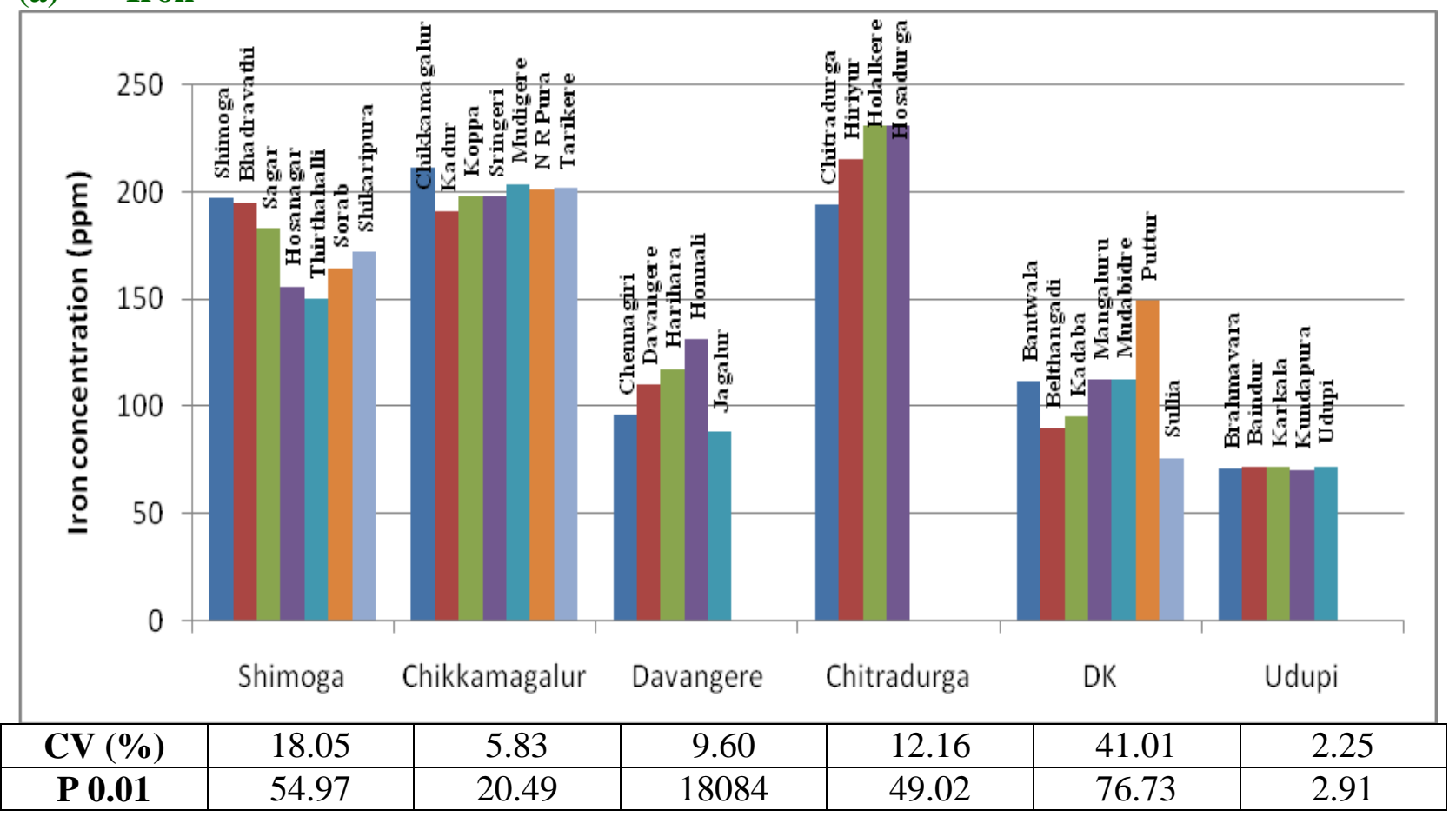

(b) Zinc

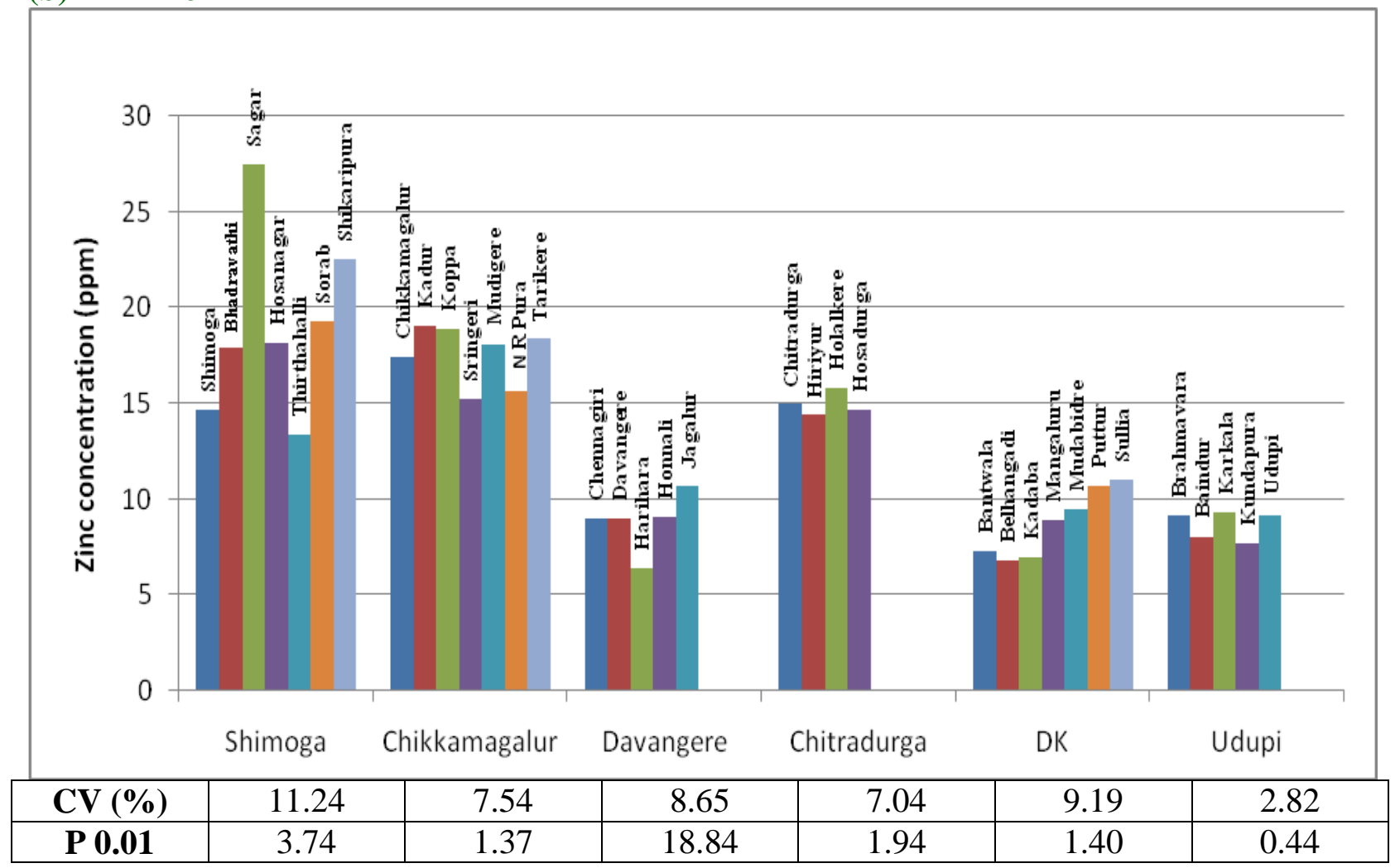


Fig.4 Taluk wise variability in Copper and Boron contents in areca samples of different districts of Karnataka

(a) Copper

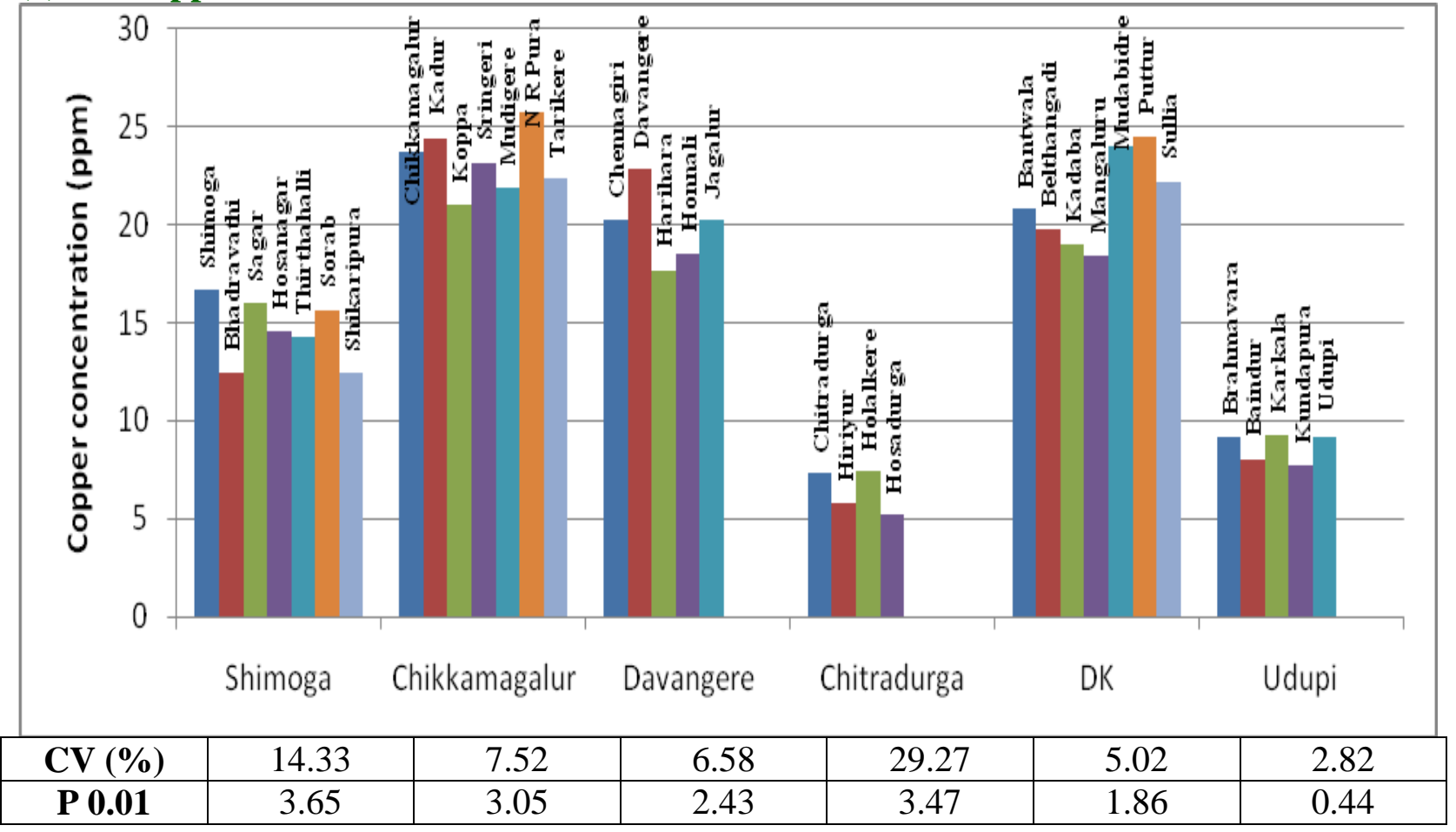

(b) Boron

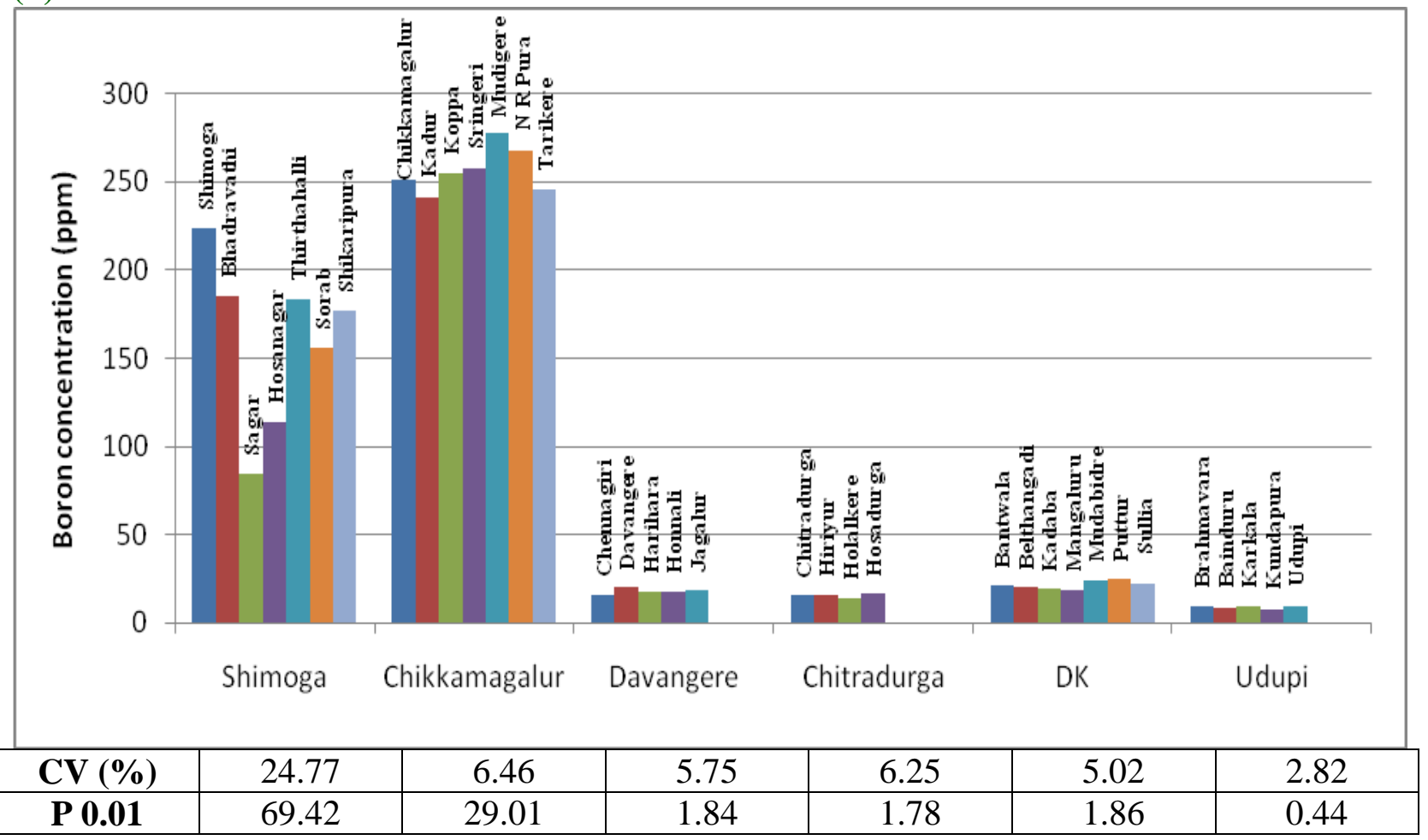


Table.1 Summary of hobliwise variability in inorganic nutrients in arecanut in different districts of Karnataka and maximum limit of areca based on critical limit of minerals

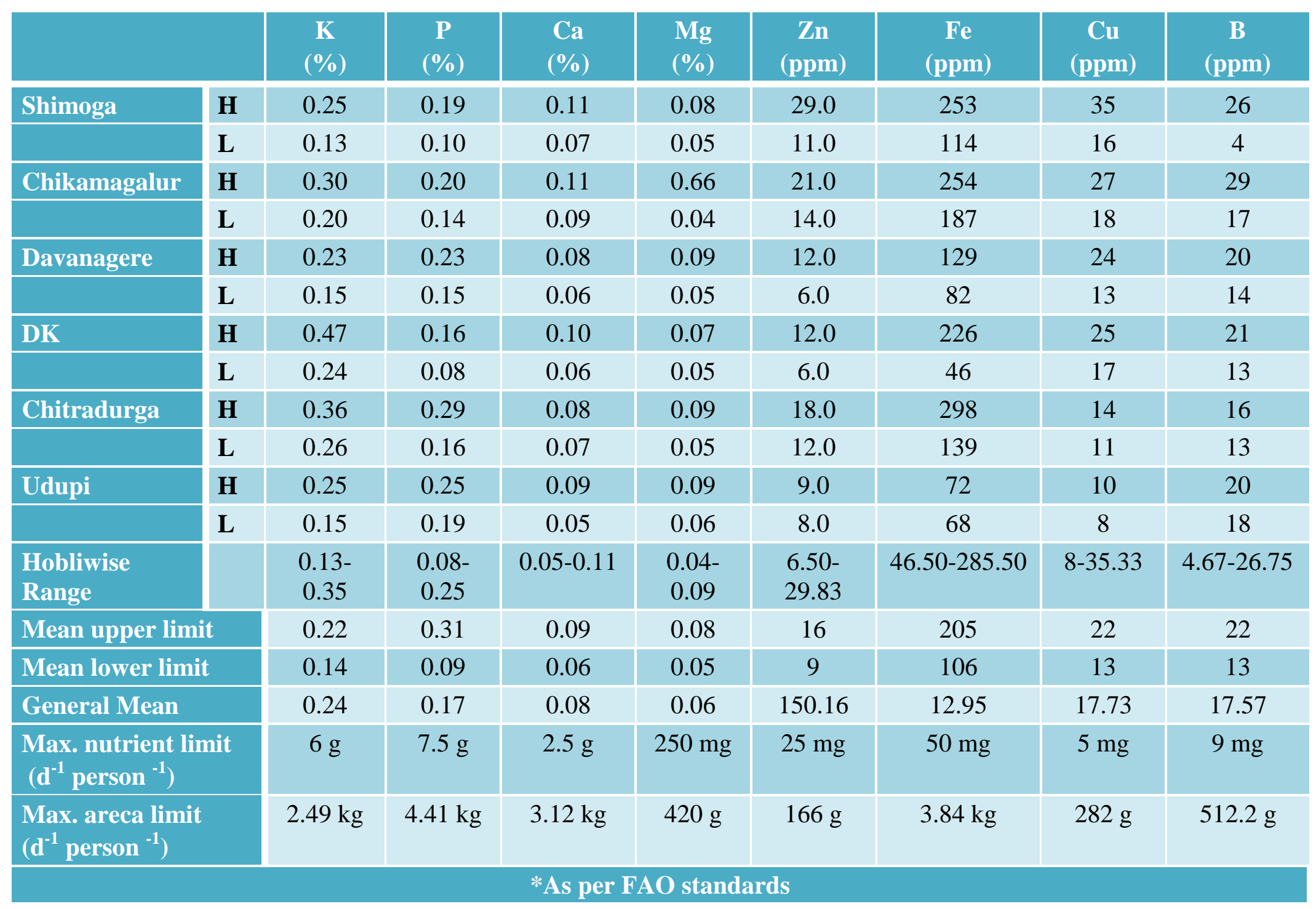


The data on the boron content of different districts is presented in Figure 4(b). Among the districts boron content recorded significant difference with the range of 7.70 to $278.03 \mathrm{ppm}$. The highest boron content was recorded in Mudigere taluk of Chikkamagalur district (278.03 ppm) which was followed by N. R. Pura taluk of Chikkamagulur district (267.86 ppm). The least boron content was recorded in Kundapura taluk of udupi (7.70 ppm).

This study contributes to the establishment of an easy and rapid ICPOES method for the determination of mineral nutrients in arecanut samples and it is found to be simple, rapid, precise, accurate and selective. In summary, the proposed method can be used for analysis of mineral nutrient content from dried areca nuts. The arecanut samples contained a mean $0.22,0.31,0.09,0.08$ percent of $\mathrm{K}, \mathrm{P}, \mathrm{Ca}$ and $\mathrm{Mg}$ as upper limit (Table 1) where as their respective lower limits were $0.14,0.09,0.06$ and $0.05 \%$. The contents of $\mathrm{Zn}, \mathrm{Fe}, \mathrm{Cu}$ and $\mathrm{B}$ were 16, 205, 22 and $22 \mathrm{ppm}$ as upper limit. The arecanut contained all the elements below the limit recommended for human consumption as the daily consumption of areca usually does not exceed 100 g per day per person. It is evident from the data presented in the Table 1, only when the daily consumption exceeds $166 \mathrm{~g}$ per day per person, the inorganic minerals reaches the critical limit that causes ill effects for human health. The concentration of nutrient content varied from area to area in different districts, this is because of agronomic practices, environmental, soil conditions, management practices and processing techniques adopted.

\section{References}

Balasimha, D and Rajagopal V., In: Introduction. Arecanut. India. Kasaragod: Central plantation crops Research Institute; 2004. p. 1-6.

Cheriyan, H and Manojkumar, K., 2014, Arecanut production scenario in India. Indian J. Arecanut, spices and Med. plants, 16: 3-11.

Lord, G. A., Lim, C. K., Warnakulasuriya, S. and Peters, T. J. (2002), Chemical and analytical aspects of areca nut. Addict. Biol., 7, 99-102.

Raghavan, V. and Baruah, H. K. (1958) Arecanut: India's popular masticatoryHistory, chemistry and utilization. Econom. Bot., 12, 315-325.

Shivashankar, S., Dhanaraj, S., Mathew, A. G., Srinivasa, M. S., Vyasamurthy, M. N. and Govindarajan, V. S. (1969), Physical and chemical characteristics of processed areca nuts. J. Food Sci. Technol., (41): 113-116

\section{How to cite this article:}

Gurumurthy, B.R., S.S. Akshatha, G. Akshay and Pavitra, S.K. 2018. Diversity of Mineral Contents in Arecanut (Areca catechu L.) in Different Locations of Karnataka, India. Int.J.Curr.Microbiol.App.Sci. 7(03): 1527-1535. doi: https://doi.org/10.20546/ijcmas.2018.703.182 